\title{
Barriers to Implement Green Road Freight Transportation: A Case Study from Malaysia
}

\author{
Subohthini Alagesan ${ }^{1}$, and Dazmin Daud ${ }^{1 *}$ \\ ${ }^{1}$ Faculty of Business and Information Science, UCSI University, Jalan Menara Gading, 56000 Cheras, Kuala Lumpur, Malaysia
}

\begin{abstract}
Green road freight transportation is at maturity stage in European countries. Many researches have been made. However, South East Asian countries had lack of study that pave way for the knowledge and application of green practices that is very shallow. However, green practices are nowadays being heard in Singapore, Malaysia and Thailand. Many initiatives are being taken in slow pace. This study is aimed to identify the barriers to implement green road freight transportation in Malaysia. The primary data is obtained through structured interview with professionals in the logistics industry particularly third-party logistics service providers. The primary data is collected through interviews which were held at the respondent's office based on their convenience. There were five respondents selected for this study. The interviewees are approached used snowballing technique. A qualitative case study approach was undertaken, and the results yielded that vehicle routing, cost and technology and awareness level are the most significant inhibitors compared to policies and legislations in Malaysia.
\end{abstract}

\section{INTRODUCTION}

The backbone to the economy success of a country is international trade. International trade refers to the development in the social welfare with a fixed amount of input or resource supply. The developments of international trade indirectly lead to the enhancement of infrastructures that are needed to facilitate the trading activities. One of the most crucial infrastructures that are required is transportation. Without transportation, any sort of movement of goods will not take place. Particularly, road freight transportation is an absolute must for any companies involved in trading.

Road freight transportation is the heart to any businesses that is existence today because a business cannot function unless the road freight is available [1]. Besides, road freight serves as a premier choice of mode of transport. For instance, goods to be shipped from one country to another have to be loaded on road freight and then delivered to the port (either airport or seaport). Most road freight carriers are trucks that operate both regionally and locally [2].

Meanwhile, assessing the road freight transportation in different countries and found that road freight transportation has always been on the rise across few years or is one of the most used mode of transport. In the United Kingdom, road freight transportation has been the highly used mode of transportation when compared to rail and sea mode of transport that are 136 billion tons, 22 billion tons and 27 billion tons respectively [3].

In the European region, an increment of $0.4 \%$ was recorded in the year 2014 when compared with year 2013. Although, this rise seems small but it was sufficient to indicate the growth of the industry as well as the comeback of the nations in the European Union after an economic recession [4]. In Brazil, $60 \%$ of cargo is carried by road. If this percentile is further scrutinized, the containerized cargo reaches up to $90 \%$. It is also claimed that road freight is preferred since its gives a flexibility to cater for JIT and shipments can be done in a smaller quantity [5].

Meanwhile, the freight transportation covers $80 \%$ of the total transportation in Malaysia. It was also highlighted in the 10th National Economic Plan that logistics service as one of the drivers to propel the country into a high income economy. In Malaysia, the nation recorded a growth of $6.8 \%$ in road freight transportation between 2009 and 2013 which plays a critical role in the distribution of freight and last-mile connectivity to seaports, airports and railway stations domestically [6].

There are many organizations such as the European Union, World Trade Organizations and the ministries of transport of various countries who has identified the impacts of emissions through their transportation industry. Many nations has taken the steps to reduce the emission but despite the efforts, the emission did not reduce significantly as a result of the increasing number of vehicles on the road.

A gap is found when Malaysian road freight transportation companies did not implement any measures to reduce their carbon footprints when many haulers run on diesel fuel and they emit harmful gases such as nitrogen oxide ( $22 \mathrm{O})$, particulate matter and carbon dioxide $(\mathrm{CO} 2)$. There are risks of health issues that will arise as a result of $\mathrm{N} 2 \mathrm{O}$ and particulate matters. However, in terms of global concern, particularly the

*Corresponding author's e-mail: dazmindaud@ucsiuniversity.edu.my 
transportation sector, greenhouse gases contributes exponentially to global warming.

Every road freight transportation service provider should realize and understand that their daily operational activities' contributes to the environment negatively. However, the failure of Malaysia road freight transportation service providers to do so creates a gap to identify the potential barriers that hinders them from taking initiatives to care for the environment. This study is aimed to identify the barriers to implement green road freight transportation in Malaysia.

\section{METHODOLOGY}

The primary data collected from the respondents were examined and analyzed with deep attention and emphasis. The primary data was obtained through structured interview with professionals in the logistics industry particularly third-party logistics service providers. The primary data was collected through interviews which held at the respondent's office based on their convenience.

This study was an exploratory research since the study aim to identify possible impacts on independent variables. Interview mode of research was used to collect the data needed for this study. The interviewees are selected based on their experiences in the logistics industry and their age also taken into consideration. Logistics industries included freight forwarding companies, shipping companies and third party logistics service providers.

There are five respondents selected for this study. The interviewees are approached used snowballing technique. The interview session is recorded used digital voice recorder as another of maintained study quality. The approximate duration of each interview held was between 10 minutes and 30 minutes. The questionnaire validity and reliability was under professor supervision in the faculty.

Semi open ended questions are developed based on the research questions and objectives. There are 5 questions developed which comprised of one demographic question and four professional questions based study questions and objectives. The validity test is performed after the questions were developed.

\section{RESULT AND DISCUSSION}

\subsection{Result}

In Table 1, Respondent 1 mentioned most crucial element was considered prior to the job acceptance. The globalization is not prevalent and e-commerce being in dubious state, the route planning was among factor to determine service quality in term of service effectiveness and cost efficiencies. Many customers expected shipments also similar to just-in-time concept. Besides, the transportation duration also need to meet the customer demand. The alternative routes are taken if the planned route is congested. Hence, the green implementation is impossible since alternatives routes might be longer way but less congested. Respondent 2 claimed that cost and time are highest priority needed to consider in conventional route. The service quality also determines the company success. The customer demand also caused transportation need to carry heavier load that over the limitation. The shipment changes also contributed to unfavorable impact to the environment compared one single haulier usage from one location to another. Respondent 3 also mentioned the availability of crucial information did not offered such as Plus highway traffic report are unavailable as predictive version of actual traffic. The customer demand also shifted towards more to ad-hoc jobs. This problem leads to the service resilience to cater. Meanwhile, Respondent 4 found that customer demand is high in Lazada, Zalora, Lelong, Groupon, and 11th street which increased customer facilities. Besides, errors in routing also affected the green environment. The errors also resulted in overweight carriage which leads more carbon release and environmental damage. Therefore, Respondent 5 mentioned globalization is increased numerous goods availabilities in Malaysia. The lack of coordination exists when the hauler at the port did not only activity.

Table 1. Barriers to implement green road freight transportation in terms of vehicle routing in Malaysia.

\begin{tabular}{ll}
\hline \multicolumn{1}{c}{ Respondent } & Explanation \\
\hline Respondent 1 & $\begin{array}{l}\text { The allowed speed limit is } 90 \mathrm{~km} / \mathrm{h} \text { in Malaysia for commercial vehicles. Nevertheless, the } \\
\text { driver has driving exceeded speed limit and drive up between } 100 \mathrm{~km} / \mathrm{h} \text { and } 110 \mathrm{~km} / \mathrm{h} .\end{array}$ \\
& $\begin{array}{l}\text { Unexpected breakdowns of the vehicles might occurred such as tire punter and ran out of } \\
\text { the fuel. The speed is increased to meet the customer demand. Therefore, the customer } \\
\text { demand and promises were more important than green concern. }\end{array}$ \\
\hline Respondent 2 & $\begin{array}{l}\text { The speed and weight capacity are elements need to concern in green route planning. There } \\
\text { also increment in purchasing power also barrier in green road freight implementation. } \\
\text { Many people tend to purchase online which difficult to envision and prepared. }\end{array}$ \\
\hline Respondent 3 & $\begin{array}{l}\text { Vehicle routing is barrier in green implementation. The road freight service was an activity } \\
\text { that carried outside locale which the business operates in. No route information availability } \\
\text { also contributed to the barrier in green road freight implementation. The customer } \\
\text { satisfaction is important such as shortest time and cost efficient is diverted to meet the } \\
\text { promise made to the customer. }\end{array}$ \\
The customer demand had skyrocketed which increased customer facilities. The customers \\
are needed to be fulfilled at any cost in peak time and non-peak time. This issue did pave \\
way for more congestion and traffic uncertainties which the customer demand and service
\end{tabular}


quality needed to fulfil.

Respondent 5 The extensive network availability that was relatively absent in Malaysia contributed to the barrier to implement green practices. Uncertainties in demand contributed as inhibiting factor to the green logistic implementation.

In Table 2, Respondent 1 mentioned two costs involved includes restructuring cost and technology cost. The restructuring cost included training cost, company policy amendment, customer relationship policy changes cost. Meanwhile, technology cost involved procuring stage of technology until successful implementation of the technology. Respondent 2 mentioned whole company had undergo a change. Human resource department would bear a significant cost in term of hiring young and competent talents to handle technology aided trailers. In technological constraints which predominant in implemented green practices was lack of technologies in developing countries. Respondent 3 mentioned high cost of implementation and unproven result is remained a barrier to implement the green road freight transportation in Malaysia. Furthermore, Respondent 4 mentioned the investment required structural changes. Human resource department was heavily utilized financial resource since current employees need to be trained and new personnel that were equipped with informational technological skills which required to handle the technologies. Respondent 5 claimed technological aided vehicles in term of corrective and preventive maintenance. Any problem found in these infrastructures was hampered the implementation of green implementation of green road freight transportation.

Table 2. Barriers to implement green road freight transportation in terms of cost and technology in Malaysia.

\begin{tabular}{ll}
\hline \multicolumn{1}{c}{ Respondent } & \multicolumn{1}{c}{ Explanation } \\
\hline Respondent 1 & $\begin{array}{l}\text { The feasibility of the implementation is hampered. The second is technological cost which } \\
\text { involved right from procuring technology stage until successful technology } \\
\text { implementation included corrective and preventive maintenance to be undertaken came } \\
\text { under technological cost. }\end{array}$ \\
\hline Respondent 2 & $\begin{array}{l}\text { The cost of implementation was utmost petrifying element in term of non-implementation } \\
\text { of such practices. }\end{array}$ \\
\hline Respondent 3 & $\begin{array}{l}\text { Heavy investment is barrier for most logistics players in Malaysia. The investment was } \\
\text { definitely being absorbed in the cost price. The lack of progress in terms of road freight } \\
\text { technologies that proven results on achieved both cost efficiency and customer satisfaction. }\end{array}$ \\
\hline Respondent 4 & $\begin{array}{l}\text { The financial strength of the organization was in good condition. Daily operation is carried } \\
\text { out with ease for fact that current reserves were sufficient. }\end{array}$ \\
\hline Respondent 5 & $\begin{array}{l}\text { The technology implementation which cost was incurred. The green road freight } \\
\text { transportation was implemented and technology was used. }\end{array}$ \\
\hline
\end{tabular}

In Table 3, the attention is given to adhere to the regulation such as driving within the speed limit and carried allowed weight. A new implementation required many changes that organization was unwilling to change. The support needed from internal stakeholders, external stakeholders and customers. Many customers expected for good services that able to deliver in time manger and cost efficient. The awareness and pressure was initiated from outside but not from internal. For the current practice, measurement such as adhering to the speed limit and weight limits is always strived to achieve for all cost.

Table 3. Barriers to implement green road freight transportation in term of awareness and readiness level in Malaysia.

\begin{tabular}{ll}
\hline \multicolumn{1}{c}{ Respondent } & \multicolumn{1}{c}{ Explanation } \\
\hline Respondent 1 & $\begin{array}{l}\text { The awareness level of green practices was widespread but personal implementation in the } \\
\text { daily operation in the organization is perceived as not needed. The need for } \\
\text { implementation was only arise if there is pressure or requirement from the stakeholders. }\end{array}$ \\
\hline Respondent 2 & $\begin{array}{l}\text { The awareness and readiness level of green road freight transportation implementation was } \\
\text { low. The view of implementation cost created an attitude of reluctance to the green road } \\
\text { freight transportation implementation. }\end{array}$ \\
\hline Respondent 3 & $\begin{array}{l}\text { The awareness and readiness level did not fall within high importance category. The } \\
\text { awareness prevails within the organization and awareness level from outside organization } \\
\text { was prevail in same frequency. }\end{array}$ \\
\hline Respondent 4 & $\begin{array}{l}\text { The awareness to implement green road freight transportation come from the customer. } \\
\text { The organization had followed the customer demand if the customer focused only service } \\
\text { quality and cost. }\end{array}$ \\
\hline Respondent 5 & $\begin{array}{l}\text { The green road freight transportation was uneasy task which required lot structural changes } \\
\text { involved. The current implementation was consumed lot times and cost and was } \\
\text { unnecessary. }\end{array}$ \\
\hline
\end{tabular}


In Table 4, Puspakom inspects the carbon emission which stated numbers did not understood clearly but clearly which wrote that mandatory to perform carbon emission test. The business performed within allowed freedom which there is absence of trouble to carry out business in Malaysia. The Puspakom inspection was

Table 4. Barriers to implement green freight transportation in term of policies and legislations in Malaysia.

\begin{tabular}{ll}
\hline \multicolumn{1}{c}{ Respondent } & \multicolumn{1}{c}{ Explanation } \\
\hline Respondent 1 & Most evidence policy was Puspakom inspection on the carbon releases. \\
\hline Respondent 2 & $\begin{array}{l}\text { The policies and legislations in Malaysia are quite normal as long as individual performed } \\
\text { business within allowed freedom which there was absence of trouble to carry out business } \\
\text { in Malaysia. Hence, no barrier was observed in green warehouse implementation. }\end{array}$
\end{tabular}

\begin{tabular}{ll}
\hline Respondent 3 & $\begin{array}{l}\text { The barriers to implement green road freight transportation in terms of legislation and } \\
\text { policies in Malaysia were almost zero. }\end{array}$ \\
\hline Respondent 4 & $\begin{array}{l}\text { Legislation in Malaysia was quite clear cut and not complicated. The inspection in } \\
\text { Puspakom was done regularly. Hence, no any barrier in term of green road freight } \\
\text { transportation. }\end{array}$ \\
\hline Respondent 5 & $\begin{array}{l}\text { The rules and regulations in Malaysia were in within not too tight and too loose. However, } \\
\text { legislation was favourable element to implement green road freight transportation. }\end{array}$ \\
\hline
\end{tabular}

In Table 5, highest frequency service was Singapore

which the driver had summoned for emit high carbon.

Table 5. The cross border service offered and issues related to green that was encounter.

\begin{tabular}{ll}
\hline \multicolumn{1}{c}{ Respondent } & \multicolumn{1}{c}{ Explanation } \\
\hline Respondent 1 & $\begin{array}{l}\text { Cross border services was offered as part of normal business service. The business } \\
\text { operations covered Singapore and Southern Thailand. }\end{array}$ \\
\hline $\begin{array}{l}\text { Respondent } 2 \text { and } \\
3\end{array}$ & $\begin{array}{l}\text { Cross border service was not offered. The business also concerned within peninsular } \\
\text { Malaysia. }\end{array}$ \\
\hline Respondent 4 & The cross border service was offered but did not included daily business operation. \\
\hline Respondent 5 & $\begin{array}{l}\text { Cross border service was offered as normal business operation. The service was provided } \\
\text { for Singapore and Thailand. }\end{array}$ \\
\hline
\end{tabular}

\subsection{Discussion}

Vehicle routing is one of the most important elements that are considered by any logistics service provider. As for maritime, aviation freight industry and rail freight industry, the routes are pre-fixed. However, the same does not apply road freight transportation since many alternative routes are available is cases of unwanted circumstances which is not available in other mode of freight transport. Vehicle routing is also important is road freight transportation because it is one of the major sources of carbon emission [7].

Generally, none of the respondents are seen to consider vehicle routing as a promoting factor to implement green road freight transportation in Malaysia. In contrast, the entire respondent agrees that the vehicle routing is a barrier. All the respondents state that service quality in regard to cost efficiency and timely delivery is more important than the concern for green environment.

Another barrier to implement green road freight transportation is the usage of combination of vehicles because the use of one line haul allows room for greater cost and time savings rather than the multiple changes in terms of loading and unloading to smaller vehicles such as trucks and van [8]. According to Respondent 2, the statement of $\mathrm{Li}$ and $\mathrm{Lu}$ [8] is accepted and same applies in the Malaysia environment where the use of single line done regularly as stipulated. The government had to ure the fuel with highest quality and emitted less emission test was made mandatory which reflected the government's awareness for environment care. 
such as Plus-Highway's traffic report is only available as an actual traffic report and not as a predictive version. This is a challenge for service providers to accurately anticipate the traffic congestion and certainly hampers the implementation of green road freight transportation.

All the respondents are observed more concerned about customer satisfaction and cost efficiencies rather than the concern for greening the environment. This is shows that in terms of vehicle routing, there was a major challenge to implement green road freight transportation.

Respondent 1 further stated that costs of hiring and educating employees, changes to current company policies and technological cost such as from the procurement stage to the corrective maintenance stage needs huge amount of initial investment. Respondent 2 and Respondent 4 also expressed similar views of cost of educating existing employees and hiring new employees that are technology savvy for a logistics department.

The limited availability of technologies in the developing countries such as Malaysia also known to be a barrier to implement green road freight transportation because in cases of breakdowns, the sourcing of spare parts might be difficult where the supplier network might be fragmented. The technologies should be easily available in developing countries where the technologies are frequently used. If the scenario happens, the sourcing of spare parts when in need is not difficult. Sourcing spare parts is one of the important factors to consider the implementation of green road freight transportation (Respondent 2).

However, the cost of investment has to be internalized to materialize the quick payback period. This means that the cost of the investment will be internalized and charged back to customer where the business runs the risk of directly affecting the competitive pricing (Respondent 1). Respondent 3 also states that such heavy investments will be a barrier because the cost of investment will definitely be absorbed into the business and hence, the chances of losing the pricing competitiveness.

Another crucial point to note in terms of technologies for green road transportation was the feasibility test or pilot test for green technology aided road freight transportation has yet to be passed [10]. This result indicated the low maturity levels of the technologies that had been introduced to the market this far. Respondent 3 also raised the concerns of the fool proof level of these technologies. Prior tests that are totally satisfying and convincing must be done before investing heavily in such technologies. This is because costs will be internalized as mentioned earlier but the downfall should be avoided to maintain sincerity to customers.

Many scholars agree that awareness level and readiness level to implement such practices is low. This is upheld by all the respondents as well. The lack of awareness to implement green road freight transportation is dominant as opposed to readiness level. The awareness itself is regarded as costs in some situations which are then seemed as unnecessary [11]. The lack of awareness then leads to reluctance to change and then to refusals [12].
The respondents stated that Puspakom religiously checks the carbon emission level during the stipulated inspection showed that the consistency in the rules. However, the readings are not understood and perceive that if not fined, their carbon emission level is under control. Except for a slightly different view from Respondent 1, Respondents 2, 3, 4 and 5 agrees that legislations and policies in Malaysia is not a barrier to implement green road freight transportation. Respondent 1 showed concerned on trailers that emit a lot of black smoke and the incapability of Puspakom and JPJ to fine them.

Respondent 1, 4 and 5 offered serviced to both Singapore and Thailand. Respondent 2 and 3 operated only within Peninsula Malaysia. Respondent 1 deals more with Singapore and has had summoned once and the others did not face any issues this far. It can be said that this question did not yield any significant results since out of five respondents only three offered cross border service and only one out of three had issues. Therefore, there are no major issues found in operating in countries with different legislation than Malaysia.

\section{CONCLUSION}

This study uncovered the barriers faced by logisticians to implement green road freight transportation. Latest and relevant information was gathered in order to conduct the study efficiently. Then, a conceptual framework was drawn as a result of analyzing the literatures. Primary data was collected using interviews with middle and top level management working in the logistic industry. Based on the answers, findings were stated with some future recommendations. These findings were providing a meaningful insight on the barriers to implement green road freight transportation.

\section{References}

1. Land Transport Unit of DG MOVE. 2011. Road Freight Transport Vademecum 2010 Report. European Commission.

2. Demir, E., Bektaş, T., \& Laporte, G. 2014. A review of recent research on green road freight transportation. European Journal Of Operational Research, 237, 3, 775-793. http://dx.doi.org/10.1016/j.ejor.2013.12.033

3. Department for Transport, 2016. Domestic Road Freight Statistics, United Kingdom 2015. United Kingdom Government.

4. Wahab, S.N., Sham, R., Hussin, A.A.A, Ismail, S., \& Rajendran, S.D. 2018. Urban Transportation: An Analysis on Bike Sharing Usage in Klang Valley. International Journal of Supply Chain Management, 7(5), 470-476.

5. S. Araújo, M., G. Campos, V., \& M. Bandeira, R. 2013. An Overview of Road Cargo Transport in Brazil. International Journal of Industrial Engineering And Management, 4, no.3, .151-160.

6. Ministry of Transport, 2015. Logistics And Trade 
Facilitation Masterplan (2015-2020).

7. Maden, W., Eglese, R., \& Black, D. 2010. Vehicle routing and scheduling with time-varying data: A case study. Journal of the Operational Research Society, 61, S3, 515-522. http://dx.doi.org/10.1057/jors.2009.116

8. Li, J. and Lu, W. 2014. Full truckload vehicle routing problem with profits. Journal of Traffic and Transportation Engineering (English Edition), 1, 2, 146-152.

9. Ducret, R., Lemarié, B. and Roset, A. 2016. Cluster Analysis and Spatial Modeling for Urban Freight. Identifying Homogeneous Urban Zones Based on Urban Form and Logistics Characteristics. Transportation Research Procedia, 12, 301-313.

10. Wahab, S.N., Bahar, N. \& Mat Radzi, N.A. 2019. An Inquiry on Knowledge Management in Thirdparty Logistics Companies. International Journal of Business Innovation and Research, DOI: 10.1504/IJBIR.2020.10024101

11. Ling E.K. \& Wahab, S.N. 2018. Integrity of Food Supply Chain: Going beyond Food Safety and Food Quality. International Journal of Productivity and Quality Management, DOI: 10.1504/IJPQM.2019.10019297.

12. Marchet, G., Melacini, M. and Perotti, S. 2014. Environmental sustainability in logistics and freight transportation. Journal ff Manufacturing Technology Management, 25, 6, 775-811. 